Disclosure of Interests: Soraia Azevedo: None declared, José Tavares-Costa: None declared, Ana Teresa Melo: None declared, Raquel Freitas: None declared, Marta Cabral: None declared, Marta Conde: None declared, Francisca Aguiar: None declared, Agna Neto: None declared, Ana Filipa Mourão: None declared, Filipa Oliveira-Ramos: None declared, Maria Jose Santos Speakers bureau: Novartis and Pfizer, Daniela Peixoto: None declared DOI: 10.1136/annrheumdis-2020-eular.667

\section{FRI0463 IDENTIFICATION OF EARLY CLINICAL AND LABORATORY CHARACTERISTICS OF MACROPHAGE ACTIVATION SYNDROME ASSOCIATED WITH SYSTEMIC JUVENILE IDIOPATHIC ARTHRITIS}

M. Lu' ${ }^{1}$, L. Guo ${ }^{2}$, L. Zou ${ }^{3}$, Y. Xu ${ }^{3}{ }^{1}{ }^{1}$ The Children's Hospital, Zhejiang University School of Medicine, Department of Rheumatology Immunology \& Allergy, Hangzhou, China; ${ }^{2}$ The Children's Hospital, Zhejiang University School of Medicine, Hangzhou, China; ${ }^{3}$ The Children's Hospital, Zhejiang University School of Medicine, Department of Rheumatology Immunology \& Allergy, Hangzhou, China

Background: Macrophage activation syndrome (MAS) is a severe, potentially life-threatening complication of systemic juvenile idiopathic arthritis (SJIA). However, early recognition of MAS remains challenging. Because it is clinically heterogeneous, hemophagocytosis is often not detected, and histopathological features lack the specificity associated with hemophagocytic syndromes. In addition, it is often difficult to distinguish early MAS from SJIA or sepsis-like syndromes.

Objectives: To identify early clinical and laboratory characteristics of MAS associated with SJIA.

Methods: This is a retrospective cohort study of 149 SJIA patients treated at the Children's Hospital of Zhejiang University School of Medicine between January 2010 to December 2017. All patients fulfilled 2001 ILAR criteria for SJIA, and 27 fulfilled 2016 Classification Criteria for MAS. We evaluated the clinical and laboratory features of SJIA patients with MAS and compared them to those without MAS. We focused our analysis on early MAS, which was defined as the time when the initial clinical and/or laboratory abnormalities suggestive of MAS were first detected.

Results: The clinical features associated with early MAS were hypotension, absence of arthritis and lymphadenopathy, bone marrow hemophagocytosis, central nervous system dysfunction, and gastrointestinal involvement. The best laboratory parameters for early MAS detection were platelet counts $\leq 275.0$ $\times 10^{9} / \mathrm{L}$, lactate dehydrogenase $>596.0 \mathrm{U} / \mathrm{L}$, aspartate aminotransferase $>47.0 \mathrm{U} / \mathrm{L}$, erythrocyte sedimentation rates $\leq 41.0 \mathrm{~mm} / \mathrm{h}$, ferritin $>1400.0 \mathrm{ng} /$ $\mathrm{mL}, \mathrm{D}$-dimer $>1.40 \mathrm{mg} / \mathrm{L}$, triglyceride $>1.30 \mathrm{mmol} / \mathrm{L}$, alanine aminotransferase $>33.0 \mathrm{U} / \mathrm{L}, \mathrm{C}$-reactive protein $\leq 68.0 \mathrm{mg} / \mathrm{L}$, fibrinogen $\leq 4.1 \mathrm{~g} / \mathrm{L}$, absolute neutrophil counts $\leq 5.2 \times 10^{9} / \mathrm{L}$, serum total protein $\leq 66.0 \mathrm{~g} / \mathrm{L}$, and white blood cell $\leq 9.8 \times 10^{9} / \mathrm{L}$. The combination of cytokines of IFN- $\gamma>17.1 \mathrm{pg} / \mathrm{mL}$ and IL- $10>7.8$ $\mathrm{pg} / \mathrm{mL}$ were found to be a specific and good prognostic cytokine pattern for early recognition of MAS, the sensitivity and specificity as $71.4 \%$ and $98.2 \%$. (Table 1, Fig 1, 2)

Table 1. Identification of clinical and Cytokine characteristics differentiating patients with MAS onset from SJIA patients without MAS

\begin{tabular}{|c|c|c|c|c|}
\hline Characteristics & $\begin{array}{c}\text { Sensitivity } \\
(\%)\end{array}$ & $\begin{array}{l}\text { Specificity } \\
(\%)\end{array}$ & OR $(95 \% \mathrm{Cl})$ & $\begin{array}{c}p \\
\text { value }\end{array}$ \\
\hline \multicolumn{5}{|l|}{ Clinical characteristics } \\
\hline Hypotension & 35.5 & 98.4 & $33.0(6.8-160.1)$ & 0.000 \\
\hline Absence of Arthritis & 77.4 & 85.2 & $19.8(7.4-52.7)$ & 0.000 \\
\hline $\begin{array}{l}\text { Hemophagocytosis in the bone } \\
\text { marrow }\end{array}$ & 28.6 & 97.3 & $14.5(2.0-107.5)$ & 0.009 \\
\hline $\begin{array}{l}\text { Central nervous system } \\
\text { involvement }\end{array}$ & 25.8 & 91.0 & $3.5(1.3-9.7)$ & 0.015 \\
\hline Gastrointestinal involvement & 22.6 & 91.8 & $3.3(1.1-9.4)$ & 0.029 \\
\hline $\begin{array}{l}\text { Absence of lymphadenopathy } \\
\text { Cytokine levels }\end{array}$ & 77.4 & 51.6 & $2.6(1.1-6.1)$ & 0.027 \\
\hline IFN- $\gamma>17.1 \mathrm{pg} / \mathrm{mL}$ & 82.1 & 83.6 & $49.5(15.6-156.9)$ & 0.000 \\
\hline $\mathrm{IL}-10>7.8 \mathrm{pg} / \mathrm{mL}$ & 78.6 & 93.1 & $23.5(7.9-69.5)$ & 0.000 \\
\hline $\begin{array}{l}\text { IFN- }->17.1 \mathrm{pg} / \mathrm{mL} \text { and } \\
\text { IL-10 }>7.8 \mathrm{pg} / \mathrm{mL}\end{array}$ & 71.4 & 98.2 & $142.5(28.2-720.6)$ & 0.000 \\
\hline
\end{tabular}

$\mathrm{OR}$, odds ratio. $\mathrm{Cl}$, confidence interval. PLT, platelet. $\mathrm{LDH}$, lactate dehydrogenase. AST, aspartate aminotransferase. ESR, erythrocyte sedimentation rate. FER, ferritin. D-D, D-dimer. TG, triglycerides. ALT, alanine aminotransferase. CRP, C-reactive protein. FIB, fibrinogen. ANC, absolute neutrophil count; TP, total protein. WBC, white blood cells. ALB, albumin. IL, interleukin. IFN, interferon.
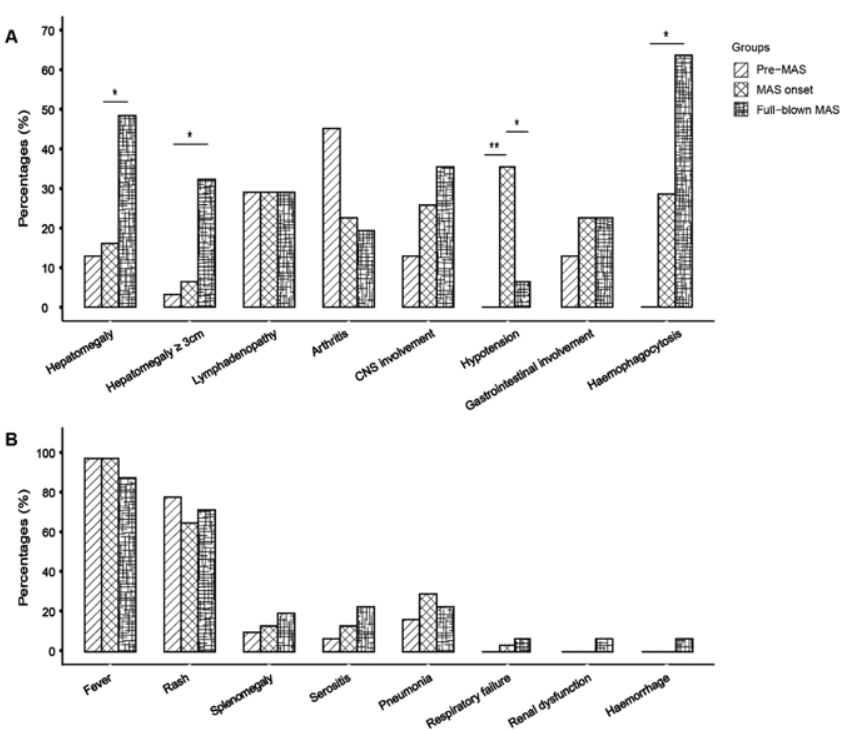

Fig 1. Comparison of clinical characteristics in the MAS process. ${ }^{*} \mathrm{P}<0.05 .{ }^{*} \mathrm{P}<0.01$.CNS involvement: Central nervous system involvement.
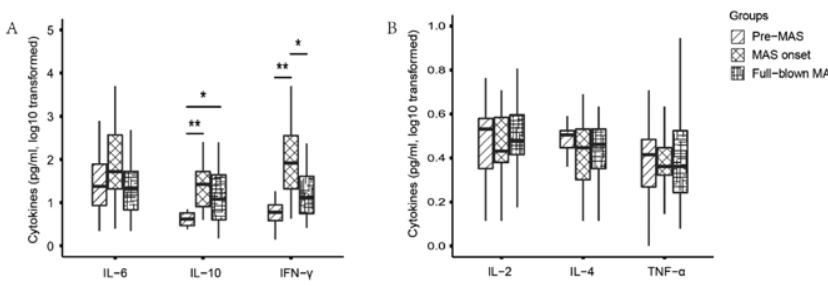

MaS onset

Fig 2. Comparison of serum cytokine levels in the MAS process. ${ }^{*} P<0.05 .{ }^{* *} P<0.01$.

Conclusion: Sudden hypotension, absence of arthritis, and significantly increased IFN- $\gamma$ and IL-10 levels are important clinical and laboratory markers for early MAS identification in addition to the traditional features of SJIA-associated MAS.

References: (not show references here)

Disclosure of Interests: None declared

DOI: 10.1136/annrheumdis-2020-eular. 1142

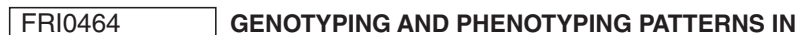 PATIENTS WITH CAPS IN RUSSIAN FEDERATION}

M. Shingarova ${ }^{1}$, E. Alexeeva ${ }^{1,2}$, T. Dvoryakovskaya ${ }^{1,2}$,

K. Savostyanov ${ }^{2}$, A. Pushkov ${ }^{2}$, E. Chistyakova ${ }^{1,2}$, K. Isaeva ${ }^{2}$, A. Chomakhidze ${ }^{2}$,

O. Lomakina ${ }^{2}$, R. Denisova ${ }^{2}$, A. Mamutova ${ }^{2}$, A. Fetisova ${ }^{2}$, M. Gautier ${ }^{2}$,

D. Vankova ${ }^{2}$, E. Krekhova ${ }^{1}$, I. Kriulin ${ }^{1,2}$, N. Zhurkova ${ }^{2}$, R. Tepaev ${ }^{1,2}$,

A. Alshevskaya ${ }^{3}$, A. Moskalev ${ }^{3} .{ }^{1}$ Sechenov First Moscow State Medical University (Sechenov University), Moscow, Russian Federation; ${ }^{2}$ National Medical Research Center of Children's Health, Moscow, Russian Federation;

${ }^{3}$ Biostatistics and Clinical Trials Center, Novosibirsk, Russian Federation

Background: Cryopyrine-associated periodic syndromes (CAPS) are a group of rare congenital auto-inflammatory diseases (AID) that include diseases such as familial cold auto-inflammatory syndrome (FCAS), Muckle-Wells syndrome (MWS), and CINCA/NOMID syndrome. At present, there are limited data on demographic and clinical features of children with CAPS in Russia.

Objectives: To reveal demographic, genotype and phenotype characteristics in CAPS patients at the National Medical Research Center of Children's health, Moscow, Russia.

Methods: Retrospective study included 12 patients (7 females, 58.3\%) with CAPS confirmed by next generation sequencing (NGS). Median age of disease onset was 5.7 (interquartile range (IQR) 0.5:12.8) years. Characteristics of disease onset as well as dynamics of disease activity during long-term treatment were evaluated.

Results: At the onset, systemic features were as follows: fever in 11 (91.6\%) patients, rash in $8(66.7 \%)$, hepatosplenomegaly in $7(58.3 \%)$ patients, and lymphadenopathy in $6(50 \%)$. Active arthritis in the onset of the disease was in $9 / 12$ 